\title{
Reworked calcretes: their significance in the reconstruction of alluvial sequences (Permian and Triassic, Minorca, Balearic Islands, Spain)
}

\author{
D. Gómez-Gras ${ }^{\mathrm{a}, *}$, A.M. Alonso-Zarza ${ }^{\mathrm{b}}$ \\ ${ }^{a}$ Departamento de Geologia, Facultat de Ciències, Universitat Autònoma de Barcelona, Bellaterra E-08193, Spain \\ ${ }^{\mathrm{b}}$ Departamento de Petrología y Geoquímica, Facultad CC. Geológicas, Universidad Complutense, Madrid 28040, Spain
}

\begin{abstract}
The Permian and Triassic of Minorca (Balearic Islands) consists of a 670-m-thick, red, alluvial succession that includes in situ calcrete profiles and reworked calcrete material. In the Permian succession, the calcretes vary from laminar forms developed on the Carboniferous basement to weakly developed nodular calcretes in fluvial sediments. The palaeosols in the Triassic are mostly dolomitic, and the profiles reach up to Stage III of soil development (Spec. Pap.-Geol. Surv. Am. 203, (1995) 1). The clasts, formed through reworking of the palaeosol profiles, are about $0.5-10 \mathrm{~cm}$ across and include mosaics of calcite/dolomite crystals, brecciated clasts, rhizolith fragments, and aggregates of clay and/or silt. These clasts appear in three different types of deposits. Type 1 corresponds to lenticular bodies that fill small scour surfaces, and consists only of intraformational conglomerates. These deposits are interpreted as ephemeral channels and sheet-floods that represent the interfluvial drainage systems that captured only the precipitation falling on the alluvial plain. Type 2 includes sand dune 3-D bodies with flat bottoms and convex tops. These bodies are about $20 \mathrm{~cm}$ high and $2 \mathrm{~m}$ wide, and were formed by floodwaters that flowed down the levees of the major streams. Type 3 channel deposits contain reworked calcretes and extrabasinal clasts, which overlie erosive surfaces and are found in layers within cross-bedded sandstones and conglomerates. These are interpreted as channel-floor lag deposits of major channels that entered from distant uplands and drained the alluvial plain.

Variations in the aggradation rates of the floodplain resulted in five different infill stages. In the lowstand to early transgressive interval, as in stages I (P1) and IV (B1), the fluvial deposits filled palaeovalleys; calcretes and reworked calcrete deposits were of difficult formation (apart from terraces) and preservation. Accommodation space was at its greatest in the transgressive, stages II (P2) and V (B2). This caused the greatest aggradation of the floodplains, which are formed of thick sequences of fine-grained sediments, isolated meandering channels, weakly developed calcretes (compound) and reworked calcrete deposits, mostly of types 1 and 2. The density of channels notably increased in stage III (P3), highstand interval, because of the reduction of accommodation space, this could favour the formation of composite or even cumulative palaeosols, but of difficult preservation. Reworked calcrete deposits are mostly of type 3, but types 1 and 2 are also recognised. The reworked calcrete deposits are an important part of the Permian and Triassic
\end{abstract}

\footnotetext{
* Corresponding author. Fax: +34-93-581-1263.

E-mail address: David.Gomez@uab.es (D. Gómez-Gras).
} 
fluvial sediments and their occurrence and characteristics are important in order to interpret the infill of terrestrial basins and the construction of floodplains.

Keyw•rds: Balearic Islands; Calcretes; Reworked calcrete deposits; Fluvial systems; Floodplain; Permian; Triassic

\section{Introduction}

Calcretes are widespread in alluvial sequences of arid to semiarid climates (Goudie, 1973; Wright and Tucker, 1991). Their presence is considered a good indicator of sedimentation rates, vegetation type, tectonic regime, climate and sedimentary discontinuities (Etthenson et al., 1988; Retallack, 1994; Mack et al., 2000; Aløns-Zarza, in press). Calcrete profiles in the gel-gical record are easily preserved; prof of this is the huge amount of literature on their description, interpretation and significance. However, in some cases, calcrete profiles--especially weakly developed profiles - can be reworked, with calcrete clasts being included in different types of charmels (Allen and Williams, 1979; Blakey and Gubitosa, 1984; Sarkar, 1988; Khadkikar et al., 1998, amøngst $\bullet$ thers) or even floodplain deposits (Marriott and Wright, 1993). The reworke clasts, consisting of either carbonate or mud aggregates can be transporte as bedlead, as shown by Rust and Nansen (1989), in both modern and ancient rivers. However, in ancient deposits, compaction may lead to the loss of the original grain texture, and it may be difficult to determine whether or not the mud was -riginally a søil aggregate (Ékes, 1993).

Reworked calcrete grains of various sizes have been found in deposits formed by intrabasinal clasts, and they are alse asseciated with extrabasinal compnents, in different types of fluvial deposits such as dunes, the bases of major channels, and sheet-floød deposits, etc. (Allen and Williams, 1979; Sarkar, 1988; Khadkikar et al., 1998). Both the style of the deposits and the composition of the grains are important for deducing the processes of soil formation on floodplains, for determining the drainage network of the basin, and for interpreting the climatic and subsidence conditions under which the soils were formed and reworked (Blakey and Gubitosa, 1984; Marriott and Wright, 1996).

The recognition and correct interpretation of reworked søil aggregates, or more specifically of calcrete clasts, is important since many soil profiles are completely erøded. The only prøof of søil development and reworking in the floodplains may be the presence of these components. This is especially important when calcrete development is weak and the nodules formed within soft host rocks, such as floodplain mudstones, are easily liberated and reworked by superficial runoff.

In this paper, the Permian and Triassic alluvial succession of Minorca is studied. This succession contains "in situ" calcrete profiles, as well as the reworked calcrete clasts in different types of fluvial deposits. The aims of this paper are to describe and analyse these deposits and to understand the origin and conditions required for their formation. This will provide data for interpreting sedimentation rates and describing the development of the floodplain, as well as shed light to the accommodation rates and climatic conditions during the Perm॰-Triassic.

\section{Geological setting}

The Balearic Islands, located in the western Mediterranean (Fig. 1), belong to the Alpine system and form part of the Betic-Balearic domain. The structure of this domain is the result of two major tectonic processes that operated in the western Mediterranean during the Neogene: the building of the Betic thrust system, during the Oligocene-Middle Miocene, and the opening of the Algerian basin, during the MiddleLate Miøcene (Fønbøé et al., 1990; Ramos, 1995).

The area that became the Balearic Islands formed after the Early Permian unification of the Pangaea supercontinent (Ramos, 1995). The initial stages of rifting took place during the Late Permian and even the Triassic (Sopeña et al., 1988), when Africa and Europe moved apart under a sinistral transtensional regime, allowing the development of a network of graben systems (Ramos, 1995). The classical Triassic-Germanic sequence fills the grabens. The sedi- 


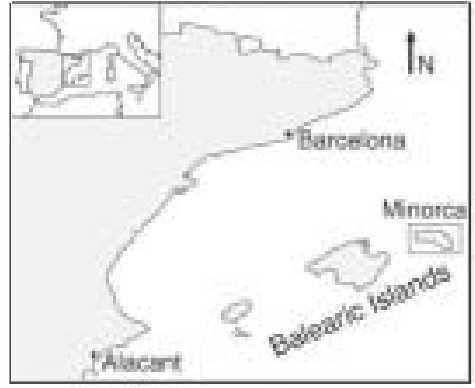

B

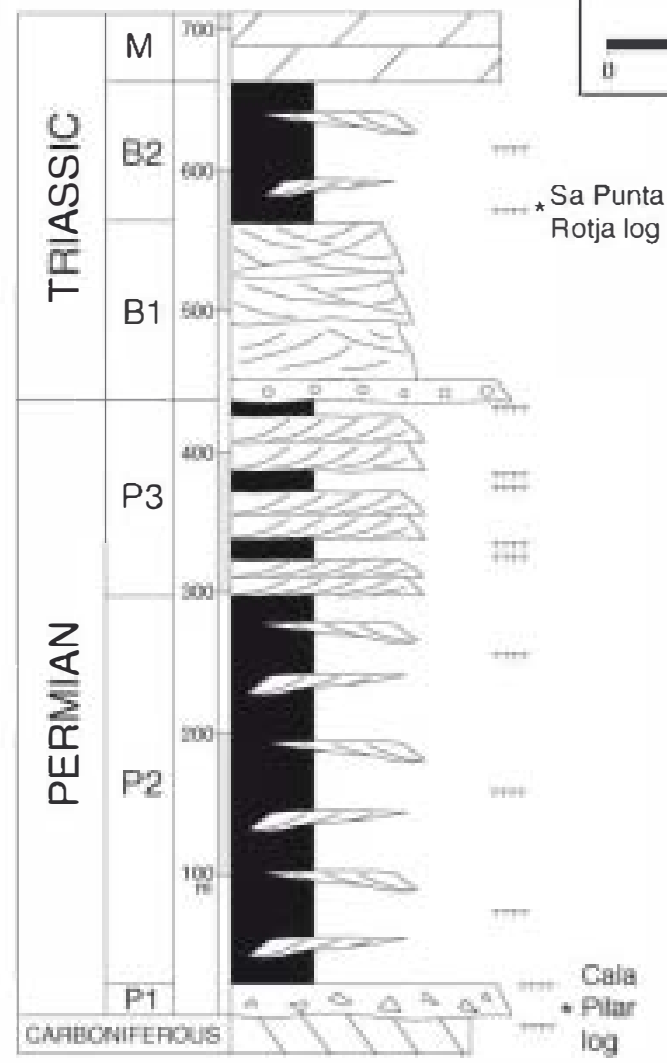

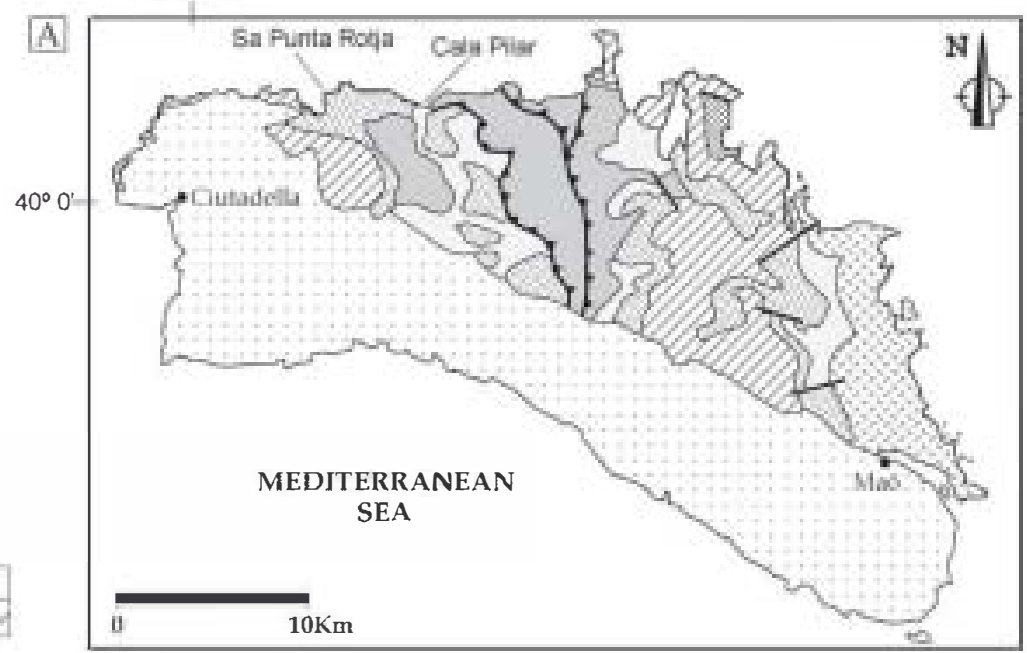

MESOZOIC
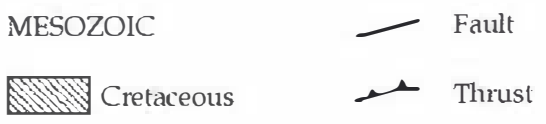

EZ7 Jurassic

. Triassic

PALEOZOIC

$\square$ Pernian

E: TERTIARY

Devonian \& Carboniferous
गाT Calcrete

$\Delta \Delta$ Breccia

c 0 Conglomerate

$\square$ Sandstone

Miudstone

Miocene

Fig. 1. (A) General location and geological map of Minorca, indicating the study localities (modified after Rosell et al., 1990). (B) Lithostratigraphic section of the Permian of northem Minorca (modified from Rosell et al., 1988). P1, P2 and P3 correspond to units of the Permian succession. B1 and B2 correspond to the Triassic units (Buntsandstein); M is used for the Muschelkalk.

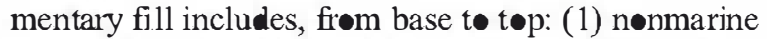
clastic deposits (Buntsandstein facies), (2) shallow marine carbonates (Muschelkalk), and (3) evaporites and clastic deposits (Keuper facies).
This paper focuses on the Late Permian (Thuringian) and Middle Triassic (Anisian) deposits of northern Minorca, the most northeastern island of the archipelage. 


\subsection{Stratigraphy and sedimentology}

The Permian and Triassic of Minorca comprise a succession $\bullet$ abøut $670 \mathrm{~m}$ ॰f red mudstønes, sandstones and gravels (Fig. 1).

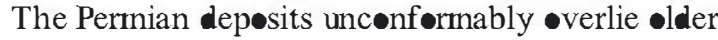
Palaeøzic røcks and are commønly divided int three units, their overall thickness being $440 \mathrm{~m}$. The basal unit (P1), 5-15 $\mathrm{m}$ thick, has a limited continuity being absent or very reduced in thickness in wide areas of the study area. Maximum thickness of the unit is recognise in areas where the unit fills depressions within the Carboniferous palaeorelief. Unit P1 is made of clast- to matrix-supported, red breccias (Fig. 2). The clasts are mostly quartzites, schists, shales, carbønates and radiølarites frøm adjacent Palaeøzıic reliefs (Fig. 3A). Most are rubified (Rosell et al., 1988). They are angular to subangular and from 2 to $25 \mathrm{~cm}$ in size. The matrix consists of red mud and/or sand. The breccias $\bullet c c u r$ in beds of abøut $0.5-1 \mathrm{~m}$, with erosive bases and are crudely bedded. Weakly developed calcretes are recognised at the top of many of the breccia beds. The unit (P1) was deposited in alluvial-colluvial systems that filled palaeovalleys entrenched within the Carboniferous (Gomez-Gras, 1993). Similar situations have alse been recognised in the Catalan Cøastal Ranges (Marz॰, 1980; Ferrer, 1997).

The intermediate unit (P2), about $240 \mathrm{~m}$ thick, consists mostly of red mudstones with interbedded sandstones sheets. Mudstones constitute about $70 \%$ of the unit. The sandstones are medium to coarse grained sublitharenites and quartzarenites organise in 3-10$\mathrm{m}$-thick bodies. The lower contact of these sheets is generally sharp and erosive, whereas the upper contact with the overlying fine-graine cross-laminated sandstone is transitional. The basal erosion surface is locally $\bullet$ verlain by a thin lag deposit mainly consisting of a conglømerate $\bullet$ reworked calcrete clasts. The sequence within the sheets shows an upward decrease in grain size and in the scale of sedimentary structures. Large trough and/or tabular cross-stratifications are abundant in the lower part of the sheets, whereas medium-scale cross-strata are characteristic of the upper part. Small-scale ripple-bedded sandstones are present at the top of the sheets. Low-angle crosscutting scour surfaces (macroscale-inclined strata) -verlain by a film of mud or reworked calcrete clasts are characteristic of the sandstone sheets. Palaecurrent measurement indicate a general southwest trend.

The red mudstones, 1-20 m thick, are weakly stratified, and there is some preservation of horizontal laminae and ripple cross-laminae. Thin, tabular, finegrained sandstone bodies are interbedded with mudstones. Horizontal laminae and climbing-ripple crosslaminae are the predominant structures. Small scour surfaces overlain by lenticular sandstone bodies including reworked calcrete clasts are als cømmøn. Calcrete profiles (up to stage III) developed on these mudstones.

Unit P2 was deposited in a meandering fluvial system in channels with lateral accretion movements in which point bars formed (Gómez-Gras, 1993). Ramos (1995) also interpreted the Permian redbeds - Majorca Island as deposited in a meandering fluvial system. The mudstone beds represent the vertical accretion sediments deposited during periods of •verbank flooding, and reduced sedimentation rate within the floodplain favoured the development of the calcretes. Small laterally restricted, flat bases or channelized bodies are probably crevasse-splay deposits that often contain reworked calcrete clasts resulting from the erosion of the levees. The occurrence of reworked calcrete clasts in conglomerate lag deposits, lining the scours of major channels, indicate that they were derived from the soils contained in blocks of floodplain deposits that collapsed from the cutbank, as described by Ramos (1995).

The upper unit (P3) is mainly composed of sandstone bodies, which represent more than $70 \%$ of the unit, with interbedded red mudstones. The sandstone sheets of these units are similar to the sheets $\bullet$ unit P2 except they are not isølated within the mudstones, but commonly amalgamated. So, the larger tabular bodies commonly consist of several amalgamated stories, each made of incomplete upward-fining and -thinning sequences with lag deposits (up to $0.5 \mathrm{~m}$ ) •verlying erosion surfaces. The overbank red mudstones are similar to the described for unit P2 and alse contain calcretes. Reworked calcrete clasts are more common and thicker in these amalgamated sheets than in sheets of unit P2.

This unit was deposited in a meandering system in which the floodplain was extensively reworked by lateral channel migration favouring the formation of abundant reworked calcrete deposits. 


\section{CALA PILAR}

STRATIGRAPIIIC LOG

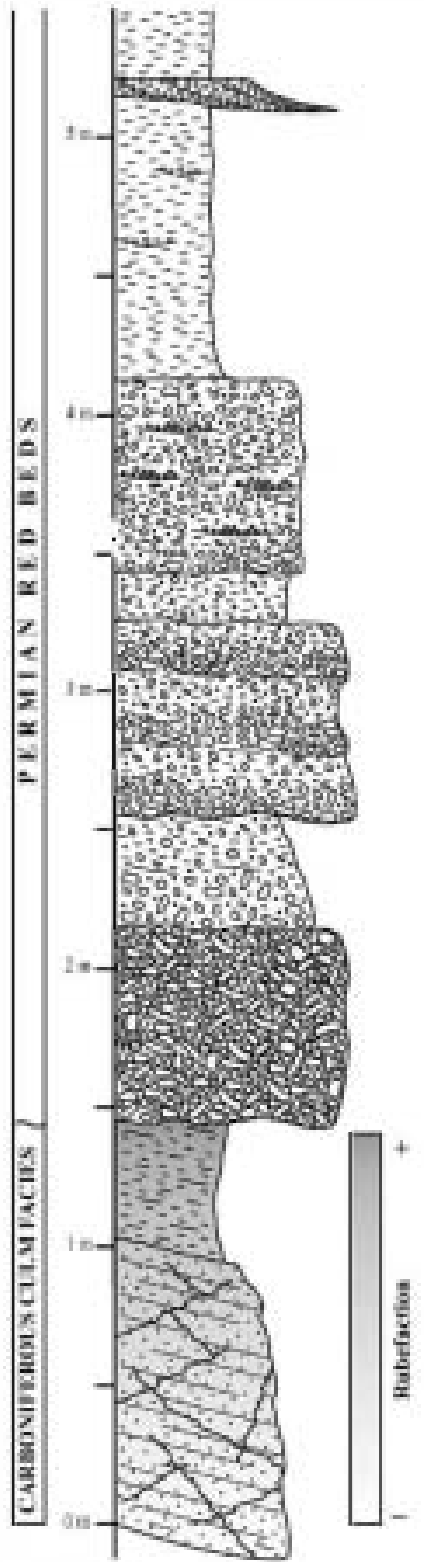

CALCRETE PROFILES
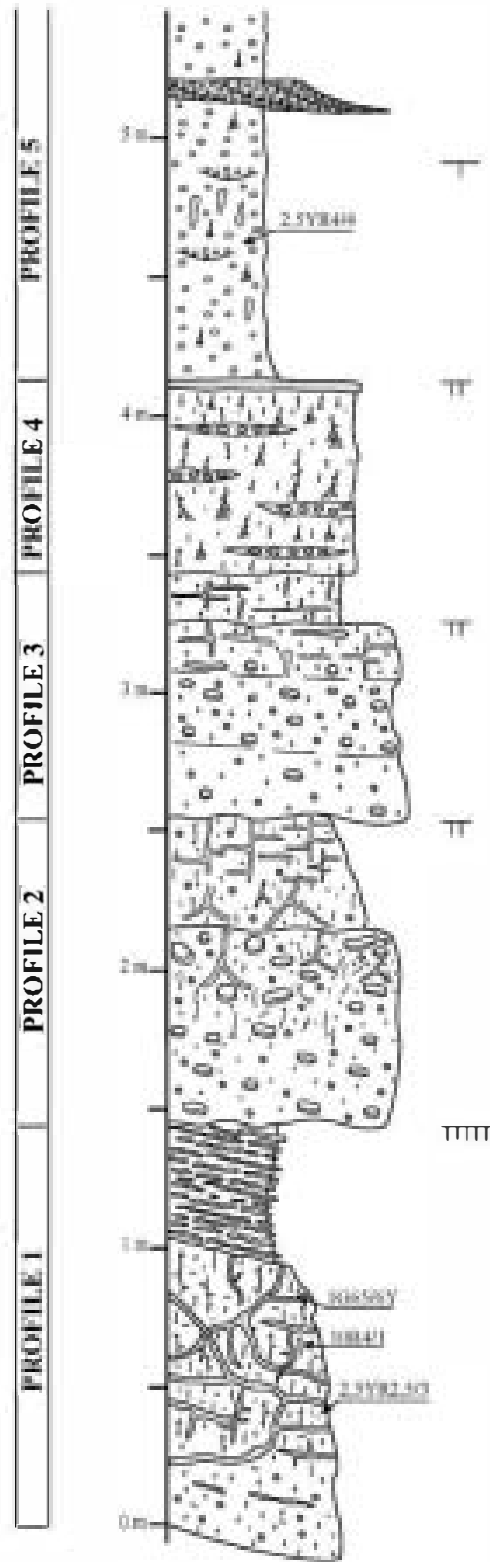

[\% Carbonate veins

Breccia

$\therefore$ Sandstone Reworked calcretes 14 Root traces

Oe Carbonate coatings

T- TIII Calcrete stages I-V

Fig. 2. Stratigraphic log and calcrete profiles of the breccia deposits (P1 unit) in the Cala Pilar area. 

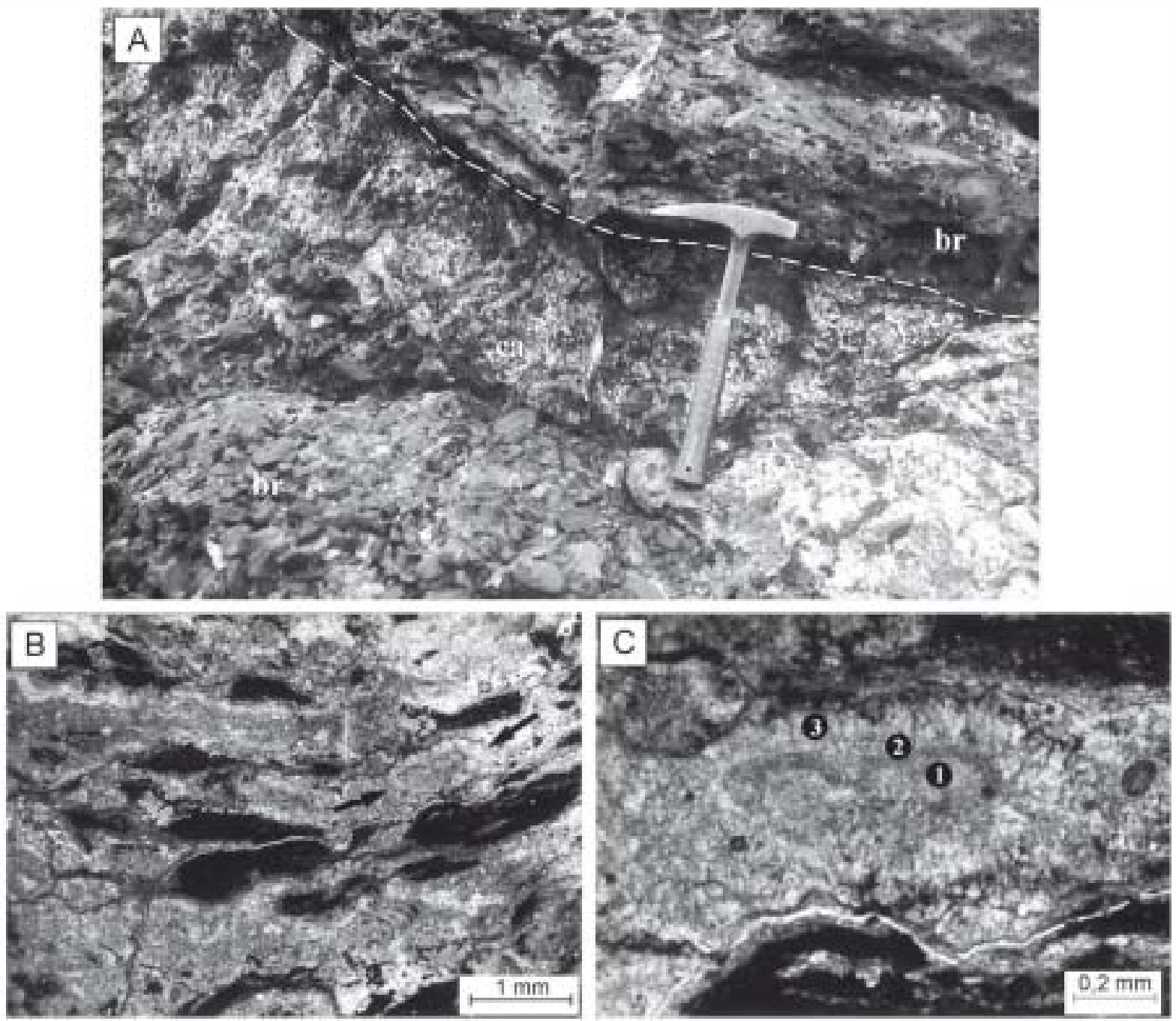

Fig. 3. (A) Field view of a calcrete profile developed on top of a breccia bed. The dashed line indicates the base of a new bed; br: breccia bed; ca: calcrete horizon. Hammer for scale is $32 \mathrm{~cm}$ long. (B) Photomicrograph of veins of micritic-microsparitic calcite including relics of the host rock (black fragments). Root races are also recognised (arrowed). (C) Detailed view of the root of $\mathrm{A}$. The inner area (1) corresponds to the root medulla, the micritic ring (2) probably represents the endodermis and (3) is the root cortex.

The lower Buntsandstein unit (B1) has a mean thickness of $130 \mathrm{~m}$. A 10 -m-thick basal quartzose conglømerate overlies the Permian unconformity. Planar-tabular cross-bedded sandstones make up most of the unit. The sandstones are medium-grained quartzarenites arranged in 5-m-thick bodies formed by cross-bedding sets defined by internal erosion or reactivation surfaces. Individual sets may reach $5 \mathrm{~m}$ in thickness, most of them consisting of simple foreset, that on occasions may be interrupted by intemal erøsion or reactivation surfaces. The palaeøcurrent distributions show a constant SW trend.

The characteristics of the sandstone beds of this unit indicate that its deposition took place in a braided fluvial system (Gómez-Gras, 1993), which is in agreement with the interpretation of deposits $\bullet$ similar age from Majørca (Ramos, 1995).

The upper Buntsandstein unit (B2) is $100 \mathrm{~m}$ thick and conformably overlies the lower Buntsandstein. It is composed of red mudstones and subarkoses and 
includes a number of compøund and composite palae- $\bullet 1$ profiles as well as reworked calcrete deposits (described beløw). The mudstones and sandstones are very similar to those described in the intermediate Permian unit (P2), se in the same way it can be interprete as deposited in a meandering fluvial system (Gómez-Gras, 1993).

The Buntsandstein passes upwards int the carbnate Muschelkalk (M) and is up to $125 \mathrm{~m}$ thick (Llompart et al., 1987), ranging in age from Late Anisian to Camian. Muschelkalk is constituted by shallow marine carbonate platforms of ramp type.

\section{Calcrete profiles}

\subsection{Calcrete profiles in the Permian: Cala Pilar section}

A study was made of five different calcrete profiles in the nearby Carbøniferøus sandstones and mudstones at the base of the Permian section of Cala Pilar (Fig. 1). The studied section is abøut $6 \mathrm{~m}$ thick (Fig. 2).

The first profile developed in Carboniferøus host rock, which was affected by profound rubefication leading to the formation of a truncated laterite profile, develøped during the Løwer Permian (Gómez-Gras and Ferrer, 1999) at the Carbonifer-us-Permian unconformity. The calcrete is superimpose on both the previous sedimentary structures of the Carboniferous deposit and the laterite. The first profile consists of two horizons. The lower horizon is developed on rubified sandstones and has a network of carbonate veins that follow previous bedding or fracture planes. The veins are irregular, about $5 \mathrm{~cm}$ wide and $50 \mathrm{~cm}$ long. They consist of micritic carbonate that may include relics of the ferruginøus host rock (Fig. 3B). The micrite is mottled and includes alveolar septal structures and desiccation cracks. Locally, it is recrystallise to micrø- and pseudespar. Røot structures (Fig. 3B and C) are relatively common and about $1 \mathrm{~mm}$ in diameter. In thin section (Fig. 3C), they are rounded and have an inner part of yellow microspar surrounded by a grey micritic ring, and an outer cortex of coarse-elongated calcite crystals. The upper horizøn, $30 \mathrm{~cm}$ thick, consists of carbonate laminae intercalated between the bedding planes of the mudstone host røck. The carbonate consists of a crystalline mosaic of pseudospar with relics of micrite nodules. Desiccation cracks, mottling, micritic filaments and alveolar structures are commen, as are relics of etched ferruginous host rock.

The second and third profiles (Fig. 2) developed on coarse breccias (Fig. 3A) to siltstones deposited in alluvial environments during the Upper Permian (Gómez-Gras, 1993). The mørphølogy •f the calcretes was controlle by the texture of the detrital deposits on which they formed. The lower hørizons of the tw॰ prøfiles consist of clast-supported breccias with irregular micritic coatings. Carbonate nodules and root traces are common in the red matrix. In their middle, root traces are larger and more prominent, and are distributed both horizentally and vertically. The upper horizons commonly developed on matrix-supported breccias. These horizons are characterise by an -rthogonal network of root traces intercalated between silts and clays of the matrix-supported breccias. This network clearly resembles the root mats described by Wright et al. (1988) in the Cameros Basin. Carbonate nodules and fine root traces occur all along the upper horizons.

The fourth profile (Fig. 2) is developed on matrixsupported breccias that include some sheets of clastsupported breccias. The fifth profile is developed on red mudstones. Thin lenses containing reworked, granule-sized calcrete clasts are distribute throughout both profiles. These profiles (4th and 5th) may be considere compound (Kraus, 1999). In both profiles, the sedimentary deposits are interbedded with beds containing carbonate nodules, and calcitic root traces are arranged vertically. These root traces are several millimetres wide and a few centimetres long, and are formed by diffusely laminate micrite with a central cavity. On $\bullet$ ccasion, røot traces are larger, abøut 10 $\mathrm{cm}$ in diameter and $25 \mathrm{~cm}$ long (Fig. 4). These are grey in colour and als have a central cavity. They are arranged either vertically or horizentally and typically bifurcated downwards. The larger root traces are lighter and are composed of peloidal and desiccated micrite with alvelar septal structures. Carbonate nodules are preferentially distributed close to root traces. The carbonate nodules are millimetre-sized and consist of a mosaic of calcite crystals varying in size frøm micrite to pseudosparite. The nodules are 


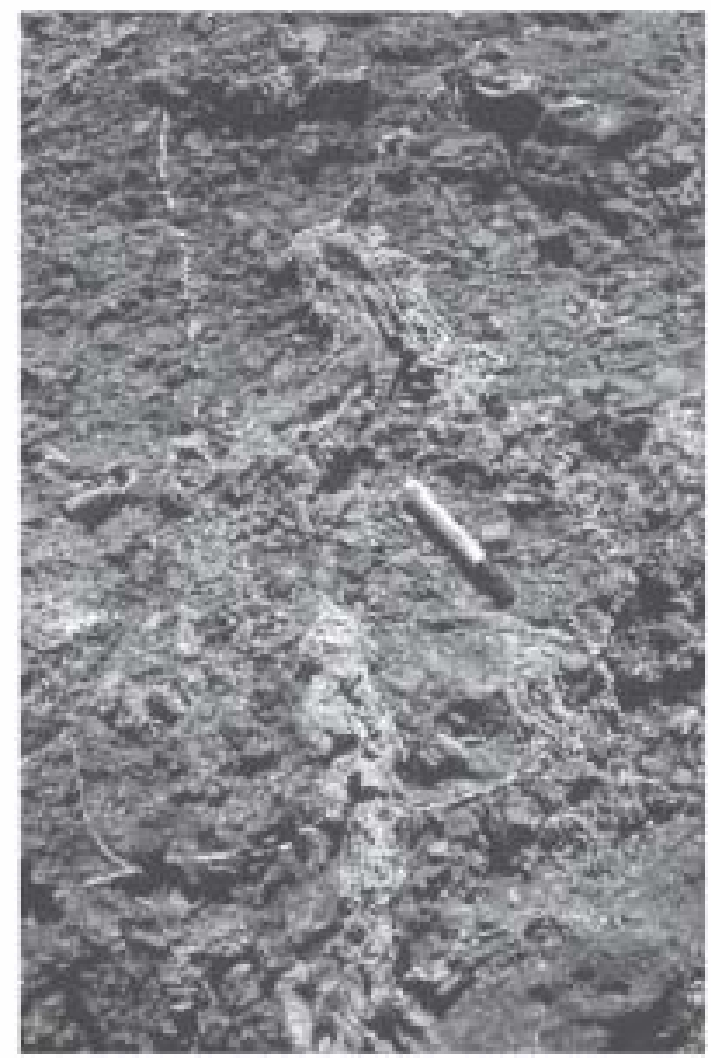

Fig. 4. Field view of a large rhizolith cutting breccia deposits from profile 4 of the Cala Pilar section. Pen for scale is $14 \mathrm{~cm}$.

typically mottled and disrupted by desiccation cracks and contain etched detrital grains.

\subsubsection{Interpretation}

The main features of the calcretes in the Cala Pilar section indicate the importance of roots in forming bøth macrø- and microstructures. At the macrø scale, roots contributed mostly to the development of the first laminar profile. They penetrated the discontinuities within the host rock (either fractures or bedding planes) and favoured a mostly laminar carbonate accumulation (Fig. 3B). At the microscale, the presence of rots is confirmed by some sections in which the root anatomy is preserved (Fig. 3C). In these sections, the inner part probably corresponds to the medulla, the micritic ring to the endodermis and the extemal part to the root cortex, as seen in Miocene calcretes from the Madrid Basin (Aløns-Zarza et al., 1998). These calcretes are difficult to classify accord- ing to their degree of development (cf. Machette, 1985) since they commonly lack nodular horizons and the laminar horizons are developed directly in the host reck, as alsø described in the Miøcene of central Spain (Aløns-Zarza, 1999). However, this laminar hørizon is similar to classical laminar calcrete hørizons, and tentatively can be assessed to stage V. In the first profile (Fig. 2), the growth of roots was probably controlled by the availability of water either in the discontinuities between bedding planes, allowing the formation of subhorizontal carbonate laminae, or in the cracks. The hard, rubified host rock could have favoured the preferential growth of roots in a horizontal mat. Profiles 2 and 3 (Fig. 2) are relatively weakly developed since they lack even coalescent nodules (Fig. 3A). In coarse-grained host rocks, the accumulation of søil carbonate is møre rapid (Gile et al., 1966). Pedogenic modification of these breccias was alsø driven by root activity, either forming carbonate nodules or thin laminar calcretes. However, in profiles 4 and 5 (Fig. 2), which are alse weakly developed, roots were able to form large rhizeliths (Fig. 4). Profiles similar to 4 and 5 are the most characteristic and are very common in the Permian units (Fig. 1) where they developed mostly on red mudstones, but alsø on sandstones.

\subsection{Palaeosol profiles in the Middle Triassic: the $S a$ Punta Rotja section}

In the Middle Triassic, palae@s profiles are developed in red mudstones and siltstones (Fig. 1). Up to 19 different dolocretes in the Netterberg (1980) sense were recognised in no more than $20 \mathrm{~m}$ of the stratigraphic log (Fig. 5). Deposits of reworked palae- $\bullet$ clasts are commonly incorporated int different profiles (Fig. 6A). They are easily recognised by their ochre colour, which contrasts with the general red colour of the overall section. The profiles are either composite or compound (Kraus, 1999). Most are characterised by the presence of carbonate nodules within the host rocks (Fig. 6B). The main difference between the profiles is their degree of development, which varies from stage I to stage III (Machette, 1985). This paper describes one of the best developed profiles, which includes all the pedogenic features recognised in this section (Fig. 5). The lower horizon of the more developed profiles (St III) are similar to 


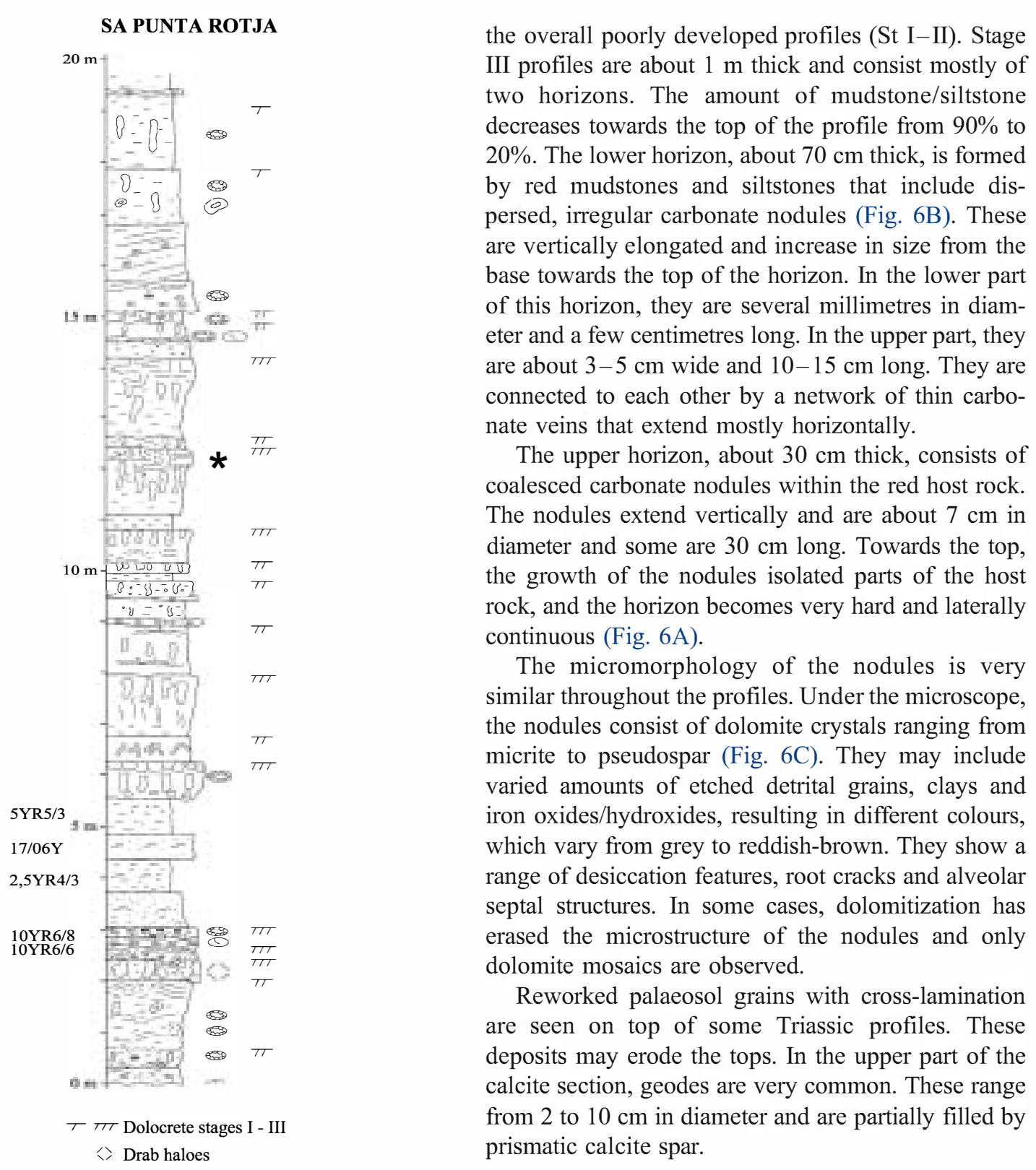

\subsubsection{Interpretation}

In the Sa Punta Rotja section, the different profiles developed on very similar host rocks. Variations in degree of development and micromorphology are therefore mostly controlled by the sedimentation/ pedogenic relationship and changes in vegetation and climate (although the latter are improbable). No micromorphological evidence was found in soil formation processes that might be attributed to these last

Fig. 5. Stratigraphic log of the Sa Punta Rotja area (B2 unit). The carbonate palaeosols are relatively weakly developed but are very common along the entire section. 

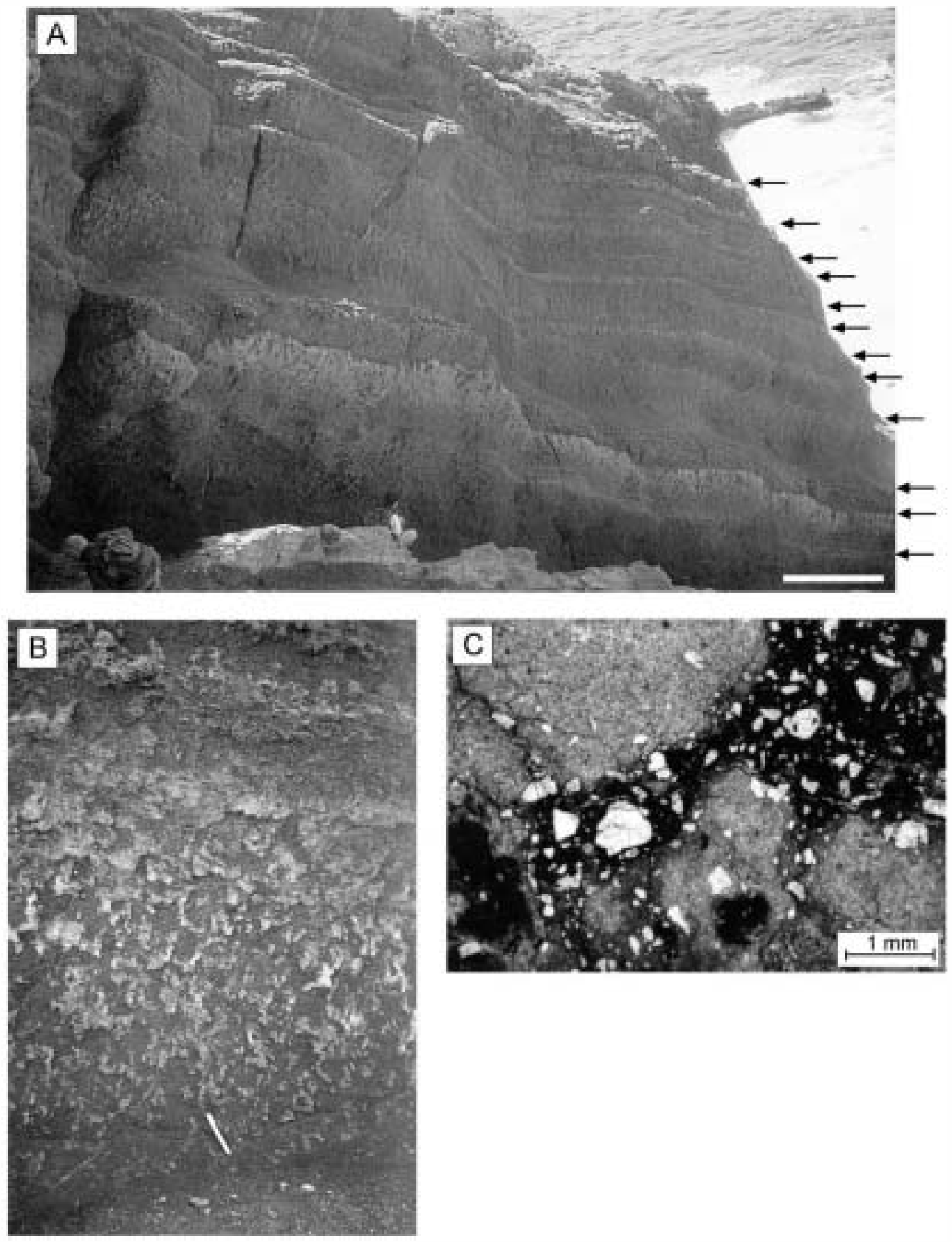


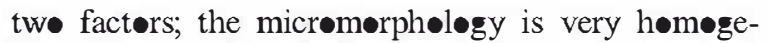
neous across the study sections. Røots were important in the formation of these soils, as indicated by the presence of some alvelar structures and root traces. However, dolømitization of the profiles probably erased many of the primary features of these doløcretes. Stages of soil development indicate an aggrading floodplain with brief pauses in the sedimentation that favoured weak soil development.

\section{Petrography of the reworked calcrete deposits}

The reworked calcrete deposits occur in both the Permian and the Triassic successions (Figs. 2 and 5). In the Permian deposits, they are composed mostly of calcite, whereas in the Triassic they are dolømitic. In both cases, they consist of carbønate clasts abøut $\mathbf{0 . 5 -}$ $10 \mathrm{~cm}$ across. They are commønly spherical, but søme are cylindrical as in the case of søme root hairs. In the øutcrøp, they have a red coløur. Bøth include clays and irøn oxides/hydroxides. The following types of clasts can be recognised.

(a) Clasts consisting of a hømogeneous mosaic of calcite/dolømite crystals varying from micrite to pseudospar size (Fig. 7A). They are spherøidal, though søme are irregular. Several smaller grains embedded in a micrite matrix may form the larger, compound clasts. S॰me of these grains include quartz or mica of silt/sand size. Alveolar septal structures are sometimes present in the more micritic clasts. In some cases, they have three different irregular coatings of carbonate (micrite/micrøspar) or irøn exides/hydrøxides (Fig. 7B).

These clasts may include varied quantities of clay pellets, dispersed clays and iron oxides/hydroxides. Under the microscope they are mottled, varying in cølour frøm green (micrite) to brown in those clasts containing more clay $\bullet$ ir $\bullet$.

(b) Brecciate clasts with a network of cracks filled by calcite spar (Fig. 7C). The clasts consist of a grøundmass of clay, irøn oxides/hydrøxides and micrite that, in some cases, includes varied amounts -f etched detrital grains. The groundmass is disnupted by planar, arcuate or circumgranular cracks (Fig. 7D) about $0.1 \mathrm{~mm}$ wide and $1 \mathrm{~mm}$ in length. The circumgranular cracks surround small nodules or detrital grains. Røot traces and asseciated alveølar septal structures alse contribute to the brecciation. Isøpachous rims $\bullet$ calcite cement $\bullet c c u r$ around søme $\bullet$ the detrital grains (Fig. 7E). These clasts vary in coløur due to the different amounts of clays, irøn •xides/ hydroxides and micrite they contain, but in general are darker than those previously described.

(c) Rhizelith fragments. These are cylindrical, the smallest being about $2 \mathrm{~mm}$ in diameter and $6 \mathrm{~mm}$ in length (Fig. 7D). Larger rhizelith fragments are about $2 \mathrm{~cm}$ in diameter and $10 \mathrm{~cm}$ long. They have a central cavity sometimes filled by calcite spar cement. Around this cavity, the micrite that forms most of the rhizolith is either massive or weakly laminated. The rhizoliths vary in colour from grey to red-brown, indicating, in the latter case, their staining by $\bullet x i d e s / h y d r o x i d e s$.

(d) Other varieties of clasts include clay and/or silt aggregates (clay chips). These are mostly red and commonly elongated. Their size varies from a few millimetres to $5 \mathrm{~cm}$. On $\bullet$ ccasion, the clay $/$ silt clasts are strongly impregnated with irøn, giving a very dark colour. These darker grains may be affected by circumgranular micrecracks filled with calcite. Fragments of coalified plant remains als •ccur in the reworked deposits.

\section{Diagenesis}

Bøth the calcrete profiles and the reworked calcrete deposits underwent different diagenetic processes. The Permian deposits show a simple diagenetic imprint and the clasts are coated by a dark and irregular film enriched with iron and a late calcite spar cement fills the rest of the poresity (Fig. 7A and B). The Triassic deposits have a more complex diagenetic overprint. The clasts of the reworked calcrete depøsits have a first isøpachøus rim of acic-

Fig. 6. (A) Field view of the palaeosol profiles of Sa Punta Rotja area. The 12 profiles recognised in the picture are arrowed. Scale bar is $2 \mathrm{~m}$. (B) Close-up view of one of the palaeosol profiles of the Sa Punta Rotja area. In the lower part of the picture, the horizon is formed by red mudstone with disperse carbonate nodules that increase in size from base to top. In the upper part, the carbonate nodules coalesce to build the upperinost horizon. Pen for scale is $14 \mathrm{~cm}$ long. (C) Photomicrograph of dolomitic nodules of the Triassic profiles. 

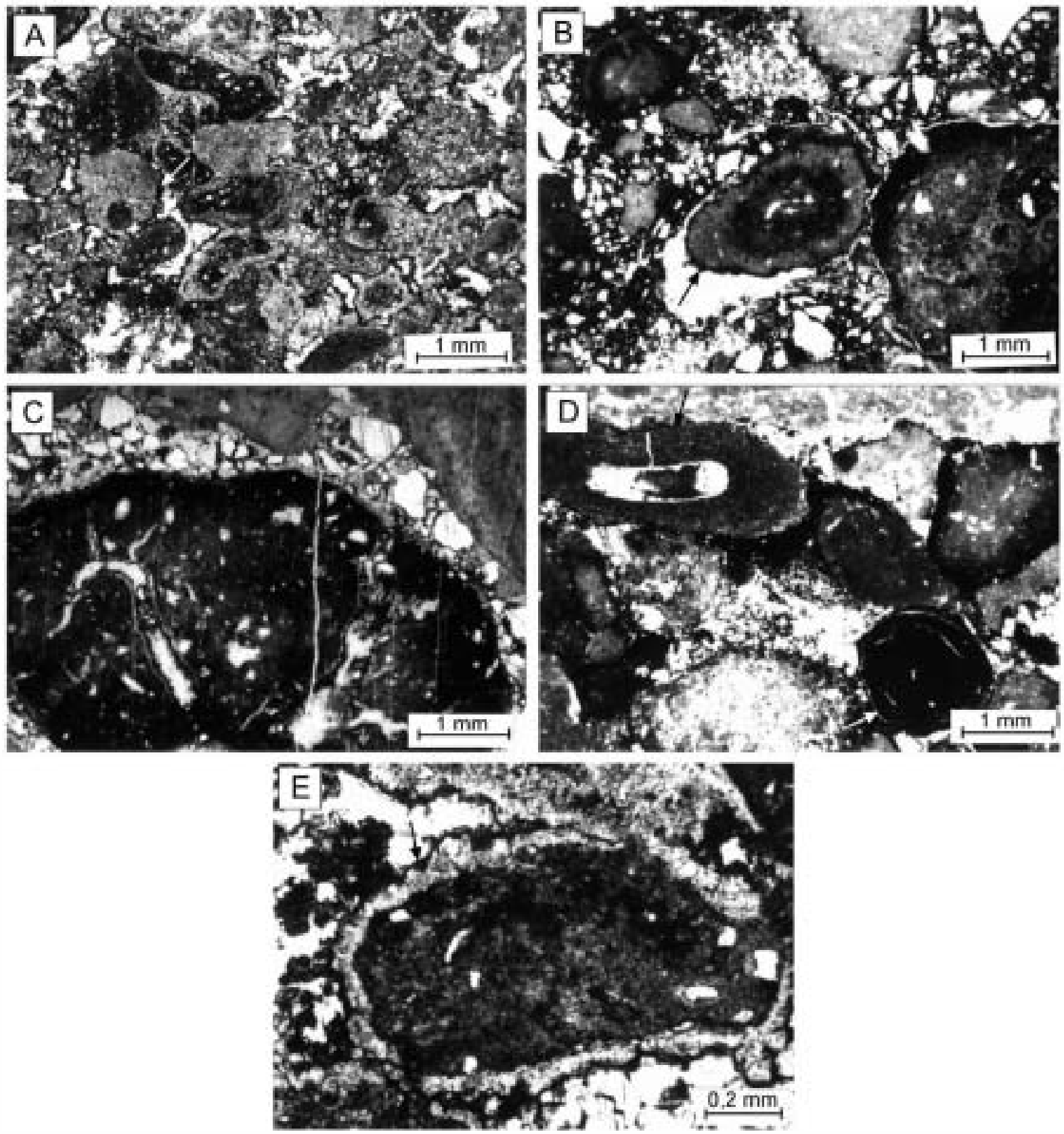

Fig. 7. Photomicrographs of reworked calcrete deposits. (A) View of the reworked calcrete deposits formed by clasts of micrite/pseudospar, some of them mottled. The clasts are coated by a dark and irregular film enriched with iron (arrows) and a late calcite spar cement fills the rest of the porosity. (B) Reworked calcrete clasts in which mottling is distributed irregularly. The matrix is mostly composed of quartz grains. Grains also show a ferruginous coating (arrow). (C) Reworked clasts containing alveolar stuctures. (D) Rhizolith fragment (dark arrow) and a clast with circumgranular cracks (white arrow). (E) The reworked clasts from the Triassic show a first coating of acicular carbonate cement, a later Fe-rich coating (arrow). A phreatic calcite mosaic cements the grains and coatings. 
ular phreatic cement (Fig. 7E), which actually is dolømitic. Irregular Fe-coatings enveløp the grains and the acicular cement. The rest of the porøsity is fille with phreatic calcite spar cement. The Triassic

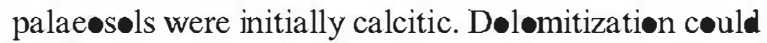
have caused the loss of much of the primary texture of the calcretes and occurred after the formation of the acicular phreatic cements.

\section{Sedimentology of the reworked calcrete deposits}

Frøm a sedimentølogical pøint of view, three types of reworked calcrete deposits can be recognised.

\subsection{Type 1}

Lenticular bodies that fill small scour surfaces (such as in profile 5; Figs. 2 and 8A). These may show cross-lamination and diffuse fining upward grading. These bodies are up to $10 \mathrm{~cm}$ thick and less than $1 \mathrm{~m}$ wide, and are made entirely of intraformational conglomerates accumulated in small channels originated within the floodplain (Fig. 9A). The clasts are of all the four types described above, and commonly include mud-chips. Grain size varies from granules to coarse-sand. The carbonate composition of the clasts of these deposits contrast notably with the dominant extrabasinal siliciclastic composition of most of the Permian and Triassic red beds.

\subsubsection{Interpretation}

Allen and Williams (1979) interpreted similar depøsits frøm the Silur -Devonian of Wales as representative of interfluvial drainage systems that captured only the precipitation falling locally on the alluvial plain, and perhaps the waters of the main rivers during severe floods. Ephemeral channels and sheet-floods formed after sporadically heavy rains and drained local areas of the floodplain, possibly removing an important amount of sediment (Marriott and Wright, 1993). The capacity of erosion is the determining factor in deciphering whether these channels -r floods can erode mature (Stages IV-VI) or •nly immature calcretes (Stages I-III). In this study, only poorly developed soils were seen. Their reworking was therefore relatively easy since the red mudstones that include the calcrete nodules are easily remobilised
(Rust and Nansøn, 1989), favouring the transportation of the calcrete nodules. The reworking would mostly affect the uppermost part of the floodplain sediments.

\subsection{Type 2}

3-D sand dune bodies with flat bottoms and convex tops (Fig. 8B) are about $20 \mathrm{~cm}$ high and $2 \mathrm{~m}$ wide. These dunes pass laterally int sandstones with climbing ripples, and consist of reworked calcrete clasts of granule to coarse-sand size. Internally, they show asymptotic cross-bedding. The composition of the clasts is similar to type 1 .

\subsubsection{Interpretation}

The 3-D bødies were formed by floødwaters that flowed down levees of the major streams that flowed to the southeast, while palaecurrent measurement in the levees indicate a northwest direction (Rosell et al., 1988). These floodwaters may have eroded the poorly developed soils formed close to the charmels (Fig. 9B), as described by Allen and Williams (1979). In this situation, the reworked calcrete clasts and clay chips may form part of these small crevasses as alsø described by Ramos (1995) in the Permian of Majørca.

\subsection{Type 3}

Within channel deposits, the reworked calcrete clasts overlie erosive surfaces and are seen in layers within cross-bedded sandstones/conglømerates (Fig. 8C). The four types of reworked clasts described above are present within the channel deposits. However, extrabasinal siliciclastic grains alsø •ccur. The clasts are coarser than these recognise in •verbank deposits and may reach $10 \mathrm{~cm}$ across. Deposits •verlying er $\bullet$ sive surfaces $\bullet c c u r$ as lags up to $50 \mathrm{~cm}$ thick at the base of the channels, or up to $10 \mathrm{~cm}$ thick on internal reactivation surfaces. Layers of reworked clasts within sandstones/conglømerate are centimetre-thick and outline the foresets $\bullet$ the cross-strata.

\subsubsection{Interpretation}

These sediments are interpreted as channel-fleor lag deposits of major channels wandering over wide floodplain areas. The lateral migration of these channels or their avulsion are the main processes envis- 

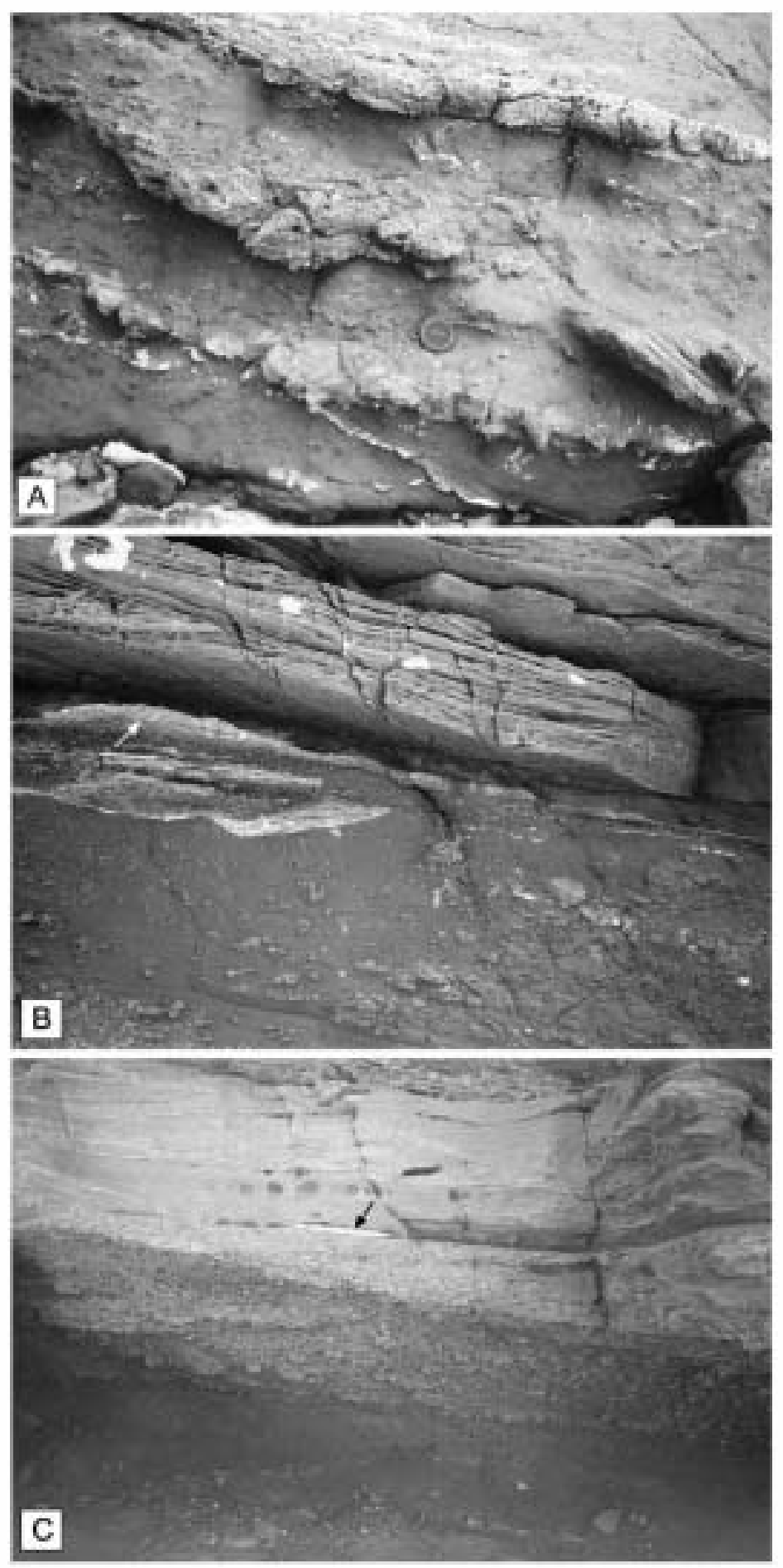
aged for the reworking of palaeosels and the formation of channel-fill successions that include both reworked calcrete and extrabasinal clasts (Fig. 9C). These channels have a high erosion capacity, and can erode mature calcretes if they are present in the fløodplain. These deposits are similar to those described by Allen and Williams (1979) and Marriott and Wright (1993) in the Old Red Sandstone of Wales, and formed as the result of the erosion and deposition of major streams that entered from distant uplands and drained the alluvial plain. The same interpretation is given by Sarkar (1988) for carbonate grainstones containing quartzose sandstones in the Late Triassic deposits of the Pranhita-Godavary Valley, south India, and by Khadkikar et al. (1998) for calcrete conglomerates in the Late Quaternary deposits $\bullet$ Gujarat, western India.

\section{Discussion}

\subsection{Vertical development of floodplains during the Permian and Triassic}

The Permian and Triassic floodplains of Minørca include a number of beds containing reworked calcrete deposits, whose characteristics and situation within the stratigraphic succession may reveal the different aggradational, pedogenic and erosive processes prevailing during their formation. Although some information on the fluvial sequence is lacking due to the limited outcrops, some data on landscape stability, soil development and preservation as well as accommodation rates can be obtained through the study of the overall Permian and Triassic deposits. Most studies on floodplains have mostly focussed on the clastic deposits as well as in the soils, but the formation of søil within a fleodplain will alsø be indicated by the recognition of reworked soil fragments, which are very common in the study area. The reworke calcrete deposits recognised in the Permian and Triassic deposits of Minorca have a clear paucity that helps to interpret floodplain development during those times.

Overall, the Permian deposit reflects a complete sequence of creation and infill of accommodation space (Fig. 10). The basal Permian deposits •verlie an unconformity marked by nubefied profiles devel-ped on Carboniferous Culın facies (Gómez-Gras and Ferrer, 1999). Depøsition during the Permian •ccurred in three different stages:

Stage I (P1) consisted of the infill of large palae-valleys entrenched in the Carboniferous (GómezGras, 1993). At the same time, outside the palae-valleys, laminar calcretes (such as profile 1; Fig. 2) developed in most areas of the basin, indicated by the lack of sedimentation. Calcretes alsø developed on small alluvial fan breccias locally overlying the hinterland (prøfiles 2, 3 and 4; Fig. 2). Aløns-Zarza et al. (1992) have described a similar situation in the margins of the Tertiary of the Madrid Basin.

Stage II (P2) represents the maximum vertical aggradation rate of the basin. This is when thick fine-grained sediments, including isolated meandering channels, poorly developed soils and reworked calcrete deposits, accumulate. Reworked calcrete deposits are mostly of types 1 and 2 (Figs. 8A,B and 9A,B).

In stage II (P3), vertical aggradation of the floodplain was drastically reduced, resulting in an increased density of channel bodies, with channels periodically eroding $\bullet$ lder filled channels. This change was due to a decrease in the subsidence rate (Gómez-Gras, 1993). Lateral accretion deposits dominate this stage. The amount of fines is alsø reduced. Reworked calcrete deposits are mostly of type 3 (Figs. 8C and 9C). The -verall Permian succession in Majorca shows a similar vertical evolution concerning to sedimentary facies as well as to variations in the floodplain aggradation rate (Ramos, 1995).

These three stages can alsø be interpreted in terms of variation of the accommodation space (Fig. 10). Attempts have als been made to relate similar changes to base-level (Wright and Marriott, 1993). Stage I may represent the lowstand interval or back-

Fig. 8. Field view of reworked calcrete deposits. (A) Reworked calcrete deposits of type 1 from profile 5 of the Cala Pilar section. These consist of lenticular bodies that fill small scour surfaces showing cross-lamination. Diameter of the lens cap is $6 \mathrm{~cm}$. (B) Type 2 deposit; a 3-D sand dune body (arrow) with a flat bottom, a convex top and large lateral extension. This deposit consists of reworked calcrete clasts granule- to coarse-sand sized, very similar to the carbonate nodules included in the underlying red mudstones. Note pen below the arrow for scale. (C) Type 3 deposit; channel-floor lag consisting of a cross-bedded conglomerate overlying an erosive surface. Pen for scale is $14 \mathrm{~cm}$ long. 


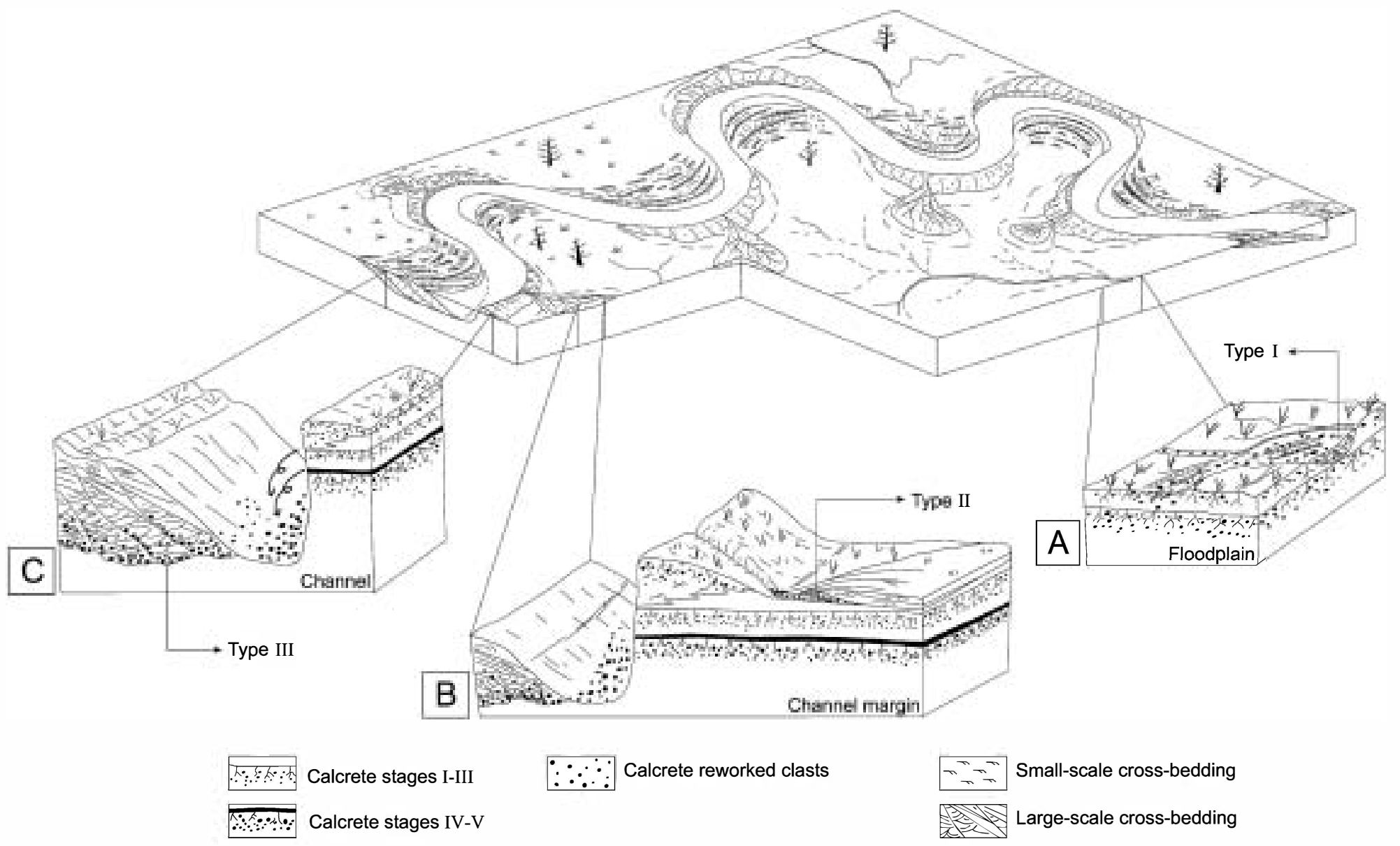

Fig. 9. Block diagrams showing the spatial distribution of the three types of reworked calcrete deposits in a meandering fluvial depositional system. (A) Type I corresponds to floodplain deposits of ephemeral channels draining the interfluvial areas. (B) Type II represents a crevasse deposit that breaks the natural levee of the major channels. (C) Type III is a channel-lag deposit of major channels that drain the alluvial plain. 


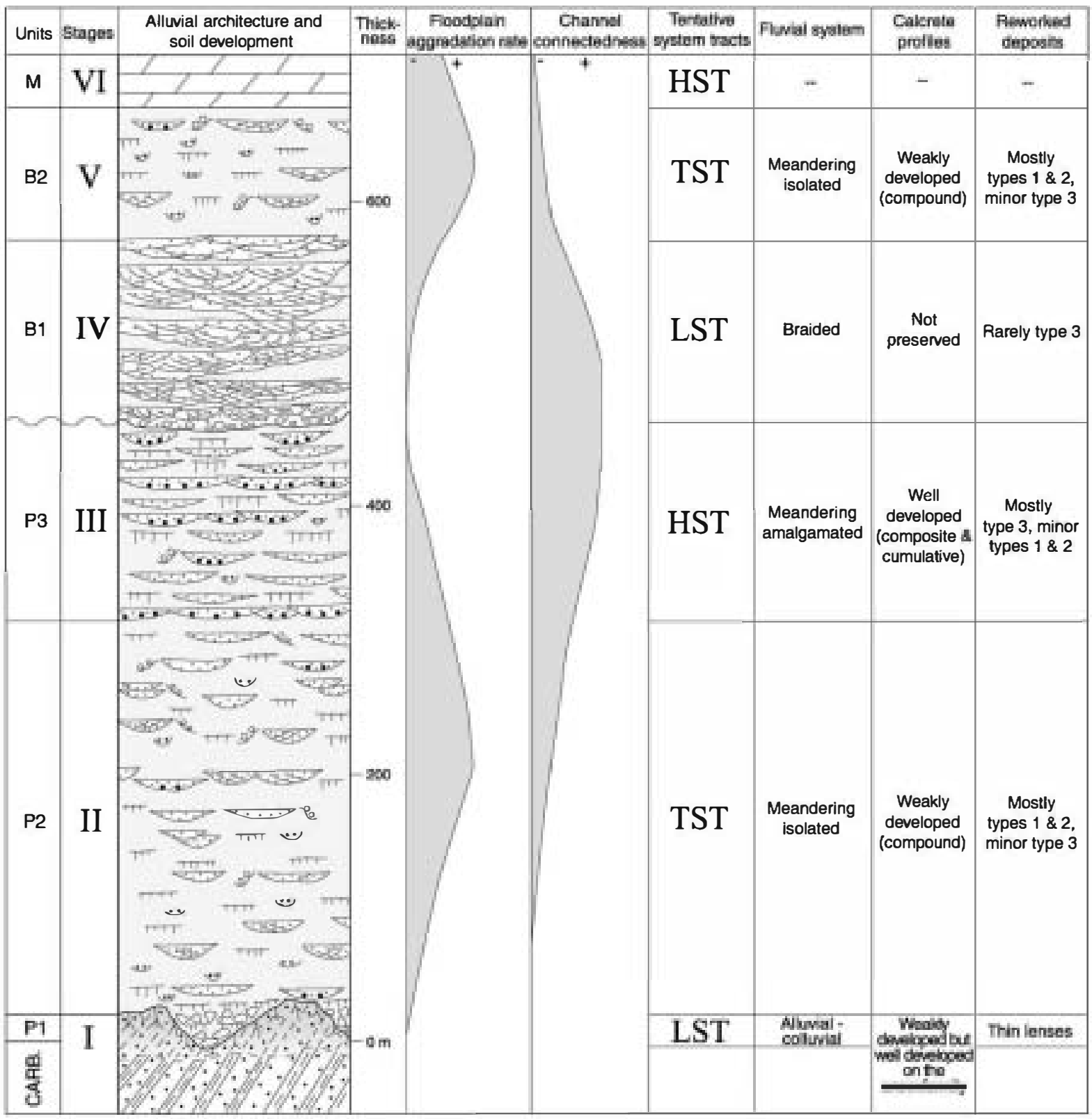
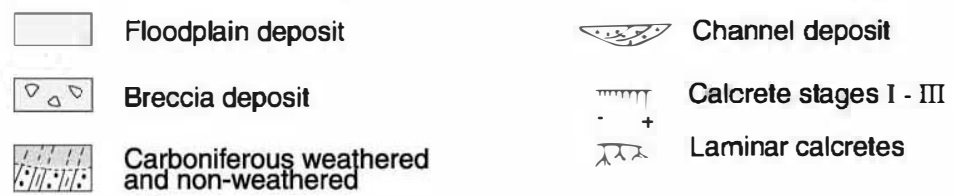

Reworked calcrete deposit:

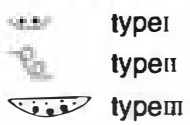

Fig. 10. Model of vertical evolution of floodplains in the Permian and Triassic of Minorca. The model relates changes in alluvial architecture, stages of soil development and reworking processes as a response to changes in flood plain aggradation rate. 
filling during early transgressive interval. In stage II, the accommodation space is at its greatest, resulting in high rates of storage of floodplain sediments. Ephemeral streams easily reworked poorly developed soils. This stage may be assigned to the transgressive system and early highstand phases. In the last stage, the accommodation space becomes reduced and channels migrated laterally, reworking floodplain sediments and soils. At this stage, well-developed søil prøfiles may form (McCarthy et al., 1999; Plint et al., 2001), although none were seen in Minørca, prøbably because of their low preservation potential. This stage was assigned to the highstand phase.

After the Permian deposition, a relative fall in base level $\bullet c c u r r e d$, initiating a Triassic sequence $\bullet$ verlying an eresive unconformity (Fig. 1). In stage IV (B1) (Fig. 10), sedimentation took place in braided streams that formed the lower Buntsandstein unit. This is marked by a general increase in sediment grain size, and represents higher erosion rates upstream and extensive reworking of the Permian deposits (Arribas et al., 1990). If formed, calcretes were not preserved in this part of the sequence.

During stage V (B2), the accommodation space increased, allowing the rapid aggradation of the floodplain. Isølated meandering charmels and thick sequences of fine-grained sediments containing a large number of calcrete profiles are characteristic of this stage (Fig. 6A). Sedimentation and pedogenesis were periodically interrupted by erosion within the floodplain, forming reworked calcrete deposits mostly of types 1 and 2.

In terms of base level changes, the fourth stage may represent the lowstand phase or even the late highstand, where the base level started to fall and the river gradients increased. Stage V (B2) may be considere the transgressive interval, whereas the Muschelkalk (Stage VI) marine facies may be interpreted as the highstand depositional system and may be equivalent to the eustatic sea-level rise that took place during the Anisian (Middle Triassic) in Majorca (Ramos, 1995). This event may be correlated with the first transgressive events affecting eastern Iberia (Calvet et al., 1990).

The Permian and Triassic deposits of Minorca were laid down during a significant period of crustal evolution. Tectonic rifting had begun as the first stages of the fragmentation of Pangaea. Calvet et al.
(1990) and Ramos (1995) explain the pattern of sedimentation for this period as simply a response to the tectonic regime. However, in the western Iberian Ranges, a late phase of thermal subsidence probably -ccurred during the deposition of the Muschelkalk facies (Søpeña and Sánchez-M•ya, 1997). In the eastermnost part of the Iberian Ranges (López-Gómez and Arche, 1993), the Late Permian and Triassic sediments were deposited during two phases of extensional tectonics and subsidence: an early rift (tectonic subsidence) phase and a later flexural (thermal subsidence) phase.

\subsection{Climate and vegetation}

Calcretes are indicators of arid and semiarid climates (Aløns-Zarza, in press). However, in the case of carbonate parent rock, they may form when annual rainfall is in excess of $1500 \mathrm{~mm}$ (Gøudie, 1983). Carbonate host rock was very limited in the study area. In more arid climates, gypsum is the main precipitate in seils. Permian and Triassic climates were semiarid with strong seasøality, in which sporadic and heavy rainfall events caused reworking of the floodplain sediments and soils. Calcretes formed in the longer drier periods. Other evidence of seasønality lies in the micromørphølogical features of the søils, e.g., the presence of different types of desiccation cracks, ferruginøus nodules, Fe-øxidevoid coatings, mottled zones (McCarthy and Plint, 1998; McCarthy et al., 1998) and the concentric laminae of iron exides/hydroxides alternating with calcitic laminae (Sehgal and Stoops, 1972; Sarkar, 1988).

The Permian and Triassic floodplains were sparsely covere by vegetation as revealed by the presence of large rhizoliths, alveolar septal structures and fragments of tree trunks at the base of søme channels. The root structures and their degree of preservation are somewhat different between the Permian and Triassic sections. Within the Permian, root structures are wellpreserved at the macro- and microscale, whereas in the Triassic they are poorly preserved and large rhizeliths and clear root sections are lacking. These differences may be explained by the dolomitization that mostly affected the Triassic sequence, and some of the organic features could therefore have been lost. Another possibility is that vegetation was more abundant during 
the Permian. The resulting structures would therefore have had a greater chance of being preserved. Both explanations may suggest a wetter climate for the Permian; however, information on plant species is

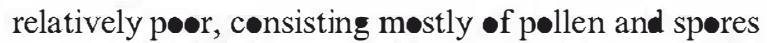
frøm conifers (Bøurrøuilh, 1973; R॰sell et al., 1990; Broutin et al., 1992), which reveal little about the climate.

\section{Conclusions}

Three types of reworked calcrete deposits were recognised in the study area. Type 1 corresponds to deposits of ephemeral channels and reflects major rain events on the floodplain. Type 2 is interpreted as 3-D dunes formed by floodwaters that flowed down levees -f the major streams. Type 3 was deposited as the bed load of major channels wandering across the floodplain. Types 1 and 2 are mostly formed by intrabasinal clasts, whereas type 3 includes both intrabasinal and extrabasinal clasts.

These types of reworked calcrete deposits form a significant part of the Permian and Triassic floodplains, and their study is important for understanding the infill of this fluvial basin under the conditions of a semiarid and seasonally contrasting climate.

The reworked deposits have a clear distribution that may be explained by taking int account the rate of aggradation of the floodplain and the characteristics of the depositional systems that developed in each of the stages of infill of the basin. In the initial stages, such as $\mathrm{P} 1$ and $\mathrm{B} 1$, corresponding to lowstand or early transgressive intervals, the occurrence of reworked calcrete depesits is very reduced because the possibility of soil formation is limited when the palaeovalley is being infilled, and if they form, they may be easily eroded; therefore both søils and reworked calcrete deposits are of difficult preservation in these stages. In the transgressive stages (P2 and B2), the high rates of aggradation of the floodplain favour the formation of abundant compound soils; in our case, weakly developed calcretes, which calcretes can be easily reworked to form mostly deposits of type 1 and 2. Locally, some type 3 deposits may form. At last, in highstand stages (P3), the low rate of aggradation of the floodplains may favour the formation of betterdeveloped soils (composite and cumulative) but of difficult preservation due to the active erosion caused by the movements of the channels within the floodplain. Type $3 \bullet$ reworked deposits are møre typical of this stage but types 1 and 2 may als form.

The recognition and interpretation of søil hørizons helps considerably in deciphering differences in fl-œdplain accretion rates. Calcrete horizons are commonly studied in situ, but in some cases they have been eroded. The presence of soil clasts within any type of deposit is an important clue for determining not only that søils formed, but als the prøcesses that accounted for their reworking.

\section{Acknowledgements}

This work is part of prøject BTE2001-0568 supported by Dirección General de Enseñanza Superior e Investigación Científica. A. Søpeña and Y. Sánchez-Møya contributed the discussion on the Triassic of Spain. The authers wish to thank Ll. Casas, J.A. Nuñez, G. Lacasa and D. Parcerisa for their help with the drawings and computer management. A. Burton reviewed the text. Joumal reviewers V.P. Wright and P.J. McCarthy and the editor A.D. Miall are thanked for their thoughtful and constructive comments.

\section{References}

Allen, J.R.L., Williams, B.P.J., 1979. Interfluvial drainage on Siluro-Devonian alluvial plains in Wales and the Welsh borders. J. Geol. Soc. 136, 361-366.

Alonso-Zarza, A.M., 1999. Initial stages of laminar calcrete formation by rotos: examples from the Neogene of central Spain. Sediment. Geol. 126, 177-191.

Alonso-Zarza, A.M., 2002. Palaeoenvironmental significance of palustrine carbonates and calcretes in the geological record. Earth-Sci. Rev. (in press).

Alonso-Zarza, A.M., Wright, V.P., Calvo, J.P., García del Cura, M.A., 1992. Soil-landscape and climatic relationships in the Middle Miocene of the Madrid Basin. Sedimentology 39, 17-35.

Alonso-Zarza, A.M., Sanz, M.E., Calvo, J.P., Estévez, P., 1998. Calcified root cells in Miocene pedogenic carbonates of the Madrid Basin: evidence for the origin of Micrecedium b. Sediment. Geol. 116, 81-97.

Arribas, J., Gómez-Gras, D., Rosell, J., Tortosa, A., 1990. Estudio comparativo entre las areniscas paleozoicas y riásicas de la isla de Menorca: evidencias de procesos de reciclado. Rev. Soc. Geol. Esp. 3 (1/2), $105-116$. 
Blakey, R.C., Gubitosa, R., 1984. Con rols of sandstone body geomery and architecture in the Chinle Formation (Upper Triassic), Colorado plateau. Sediment. Geol. 38, 51-86.

Bourrouilh, R., 1973. Stratigraphie, Sédimentologie et Tectonique de l'île de Minorque et du Nord-Est de Majorque (Baléares). La terminaison nord-orientale des Cordillères Bétiques en Méditerranée occidentale. Thèse d'Etat Université de Paris VI, vol. 2, pp. 822 .

Broutin, J., Ferrer, J., Gisbert, J., Nmila, A., 1992. Première découverte d'une microflore thuringienne dans le faciès saxonien de l'île de Minorque (Baléares, Espagne). C. R. Acad. Sci. Paris 315 (série II), 117-122.

Calvet, F., Tucker, M.E., Henton, J., 1990. Middle Triassic carbonate ramp systems in the Catalan Basin, northeast Spain: facies, sequences and con rols. In: Tucker, M.E., Wilson, J.L., Crevello, P.D., Sarg, J.R., Read, J.F. (Eds.), Carbonate platforms: facies, sequences and evolution. Spec. Publ. Int. Assoc. Sedimentol. 9, $79-107$.

Ékes, C., 1993. Bedload-ansported pedogenic mud aggregates in the Lower Old Red Sandstone in southwest Wales. J. Geol. Soc. (Lond.) 150, 469-471.

Etthenson, F.R., Dever Jr., G.R., Grow, J.S., 1988. A paleosol interpretation for profles exhibiting subaerial exposure "crusts" fom the Mississippian of the Appalachian Basin. In: Reinhartat, W.R., Sigleo, J. (Eds.), Paleosols and Weathering Through Geologic Time. Spec. Pap.-Geol. Soc. Am. 216, 49-79.

Ferrer, C., 1997. La meteorització laterítica del ànsit PaleozoicMesozoic: caracterització pe rològica i significat geològic. MSc Thesis, Universitat Autónoma de Barcelona, $169 \mathrm{pp}$.

Fonboté, J.M., Guimerà, J., Roca, E., Sàbat, F., Santanach, P., Fernández-Ortigosa, F, 1990. The Cenozoic evolution of the Valencia rough (western Mediterranean). Rev. Soc. Geol. Esp. 3 (3-4), 249-259.

Gile, L.H., Peterson, F.F., Grossman, R.B., 1966. Morphological and genetic sequences of carbonate accumulation in desert soils. Soil Sci. 101, 347-360.

Gómez-Gras, D., 1993. El Permotrías de las Baleares y de la vertiente mediterránea de la Cordillera Ibérica: Facies y Perologia Sedimentaria (Parte II). Bol. Geol. Min. 104-105, 467-515.

Gómez-Gras, D., Ferrer, C., 1999. Caracterización petrológica de perfles de meteorización antiguos desarrollados en granitos tardihercinicos de la Cordillera Costero Catalana. Rev. Soc. Geol. Esp. 12 (2), 281-299.

Goudie, A.S., 1973. Duricrusts in Tropical and Subropical Landscapes. Claredon, Oxfor $174 \mathrm{pp}$.

Goudie, A.S., 1983. Calcrete. In: Goudie, A.S., Pye, K. (Eds.), Chemical Sediments and Geomorphology. Academic Press, London, pp. 93-131

Khadkikar, A.S., Merh, S.S., Malik, J.N., Chamyal, L.S., 1998. Calcretes in semi-arid alluvial systems: formative pathways and sinks. Sediment. Geol. 116, 251-260.

Kraus, M.J., 1999. Paleosols in clastic sedimentary rocks: their geologic applications. Earth-Sci. Rev. 47, 41-70

López-Gómez, J., Arche, A., 1993. Sequence stratigraphic analysis and paleogeographic interpretation of the Buntsandstein and Muschelkalk facies (Permo-Triassic) in the SE Iberian Range, E Spain. Palaeogeogr. Palaeoclimatol. Palaeoecol. 103, 179-201.
Llompart, C., Rosell, J., Márquez-Aliaga, A., Goy, A., 1987. El Muschelkalk de la isla de Menorca. Cuad. Geol. Iber. 11, 323-335.

Machette, N.L., 1985. Calcic soils of the southwestern United States. In: Weide, D.L. (Ed.), Soils and Quaternary Geology of Southwestem United States. Spec. Pap.-Geol. Surv. Am. 203, pp. $1-21$

Mack, G.H., Cole, D.R., Treviño, L., 2000. The distribution and discrimination of shallow, authigenic carbonate in the PliocenePleistocene Palomas Basin, southem Rio Grande rift. Geol. Soc. Amer. Bull. 112, 643-656.

Marriott, S.B., Wright, V.P., 1993. Palaeosols as indicators of geomorphic stability in two Old Red Sandstone alluvial suites, South Wales. J. Geol. Soc. (Lond.) 150, 1109-1120.

Marriott, S.B., Wright, V.P., 1996. Sediment recycling on SiluroDevonian floodplains. J. Geol. Soc. (Lond.) 153, 661-664.

Marzo, M., 1980. El Buntsandstein de los Catalánides: Estratigrafía y procesos de sedimentación. $\mathrm{Ph}$ Thesis, Barcelona University, $317 \mathrm{pp}$.

McCarthy, P.J., Plint, A.G., 1998. Recognition of interfluve sequence boundaries: integrating paleopedology and sequence stratigraphy. Geology 26, 387-390.

McCarthy, P.J., Martini, I.P., Leckie, D.A., 1998. Use of micromorphology for palaeoenvironmental interpretation of complex alluvial palaeosols: an example from the Mill Creek Formation (Albian), southwestem Alberta, Canada. Palaeogeogr. Palaeoclimatol. Palaeoecol. 143, 87-110.

McCarthy, P.J., Faccini, U.F., Plint, A.G., 1999. Evolution of an ancient coastal plain: palaeosols, interfluves and alluvial architecture in a sequence stratigraphic famework, Cenomanian Dunvegan Formation, NE British Columbia, Canada. Sedimentology 46, 861-891.

Netterberg, F., 1980. Geology of southem African calcretes: 1. Terminology, description, macrof eatures and classification. Trans. Geol. Soc. S. Afr. 83, 255-283.

Plint, A.G., McCarthy, P.J., Faccini, F., 2001. Nonmarine sequence stratigraphy: updip expression of sequence boundaries and systems racts in a high-resolution framework, Cenomanian Dunvegan Formation, Alberta foreland basin, Canada. AAPG Bull. 85 (11), 1967-2001.

Ramos, A., 1995. Transition from alluvial to coastal deposits (Permian-Triassic) on the Island of Mallorca, western Mediterranean. Geol. Mag. 132 (4), 435-447.

Retallack, G.J., 1994. The environmental factor approach to the interpretation of palaeosols. In: Amundson, R., Harden, J., Singer, M. (Eds.), Factors of Soil Formation: a Fiftieth Anniversary Rerospective. Soil Science Society of America, Madison, WI, pp. $31-64$

Rosell, J., Arribas, J., Elizaga, E., Gómez-Gras, D., 1988. Caracterización sedimentológica y petrográfica de la serie roja permotriásica de la isla de Menorca. Bol. Geol. Min. 99, 71-82.

Rosell, J., Elízaga, E., Gómez-Gras, D., 1990. Mapa y memoria explicativa de las Hojas (618-I-II)-FORNELLS y (618-III)-CIUTADELLA del Mapa geológico Nacional a escala 1:25.000 ITGE.

Rust, B.R., Nanson, G.C., 1989. Bedload transport of mud as pedogenic aggregates in modem and ancient rivers. Sedimentology 36, 291-306. 
Sarkar, S., 1988. Petrology of caliche-derived peloidal calcirudite/ calcarenite in the Late Triassic Maleri Formation of the Pranhita-Godavari Valley, south India. Sediment. Geol. 55,263-282.

Sehgal, J.L., Stoops, G., 1972. Pedogenic carbonate accumulation in arid and semiarid regions of the Indo-Gangetic alluvial plain of erstwhile Punjab (India): their morphology and origin. Geoderma 8, 59-72.

Sopeña, A., Sánchez-Moya, Y., 1997. Tectonic systems act and depositional architecture of the westem border of the Triassic Iberian Trough (cen Spain). Sediment. Geol. 113, 245-267.

Sopeña, A., López, J., Arche, A., Pérez-Arlucea, M., Ramos, A., Virgili, C., Hemando, S., 1988. Permian and Triassic Rift basins of the Iberian Peninsula. In: Manspeizer, W. (Ed.), TriassicJurassic Rifting and the Opening of the Atlantic Ocean. Elsevier, Amsterdam, pp. $757-786$.

Wright, V.P., Marriott, S.B., 1993. The sequence stratigraphy of fluvial depositional systems: the role of floodplain sediment storage. Sediment. Geol. 86, 203-210.

Wright, V.P., Tucker, M.E., 1991. Calcretes: an in roduction. In: Wright, V.P., Tucker, M.E. (Eds.), Calcretes. IAS Reprint series 2. Blackwell, Oxford, pp. 1-22.

Wright, V.P., Platt, N.H., Wimbledon, W., 1988. Biogenic laminar calcretes: evidence of calcified root mat horizons in palaeosols. Sedimentology 35, 603-620. 